\title{
ASPECT IN MALAY VERBS: REALIGNING TIME AND VOLITION TO MALAY EVENTS
}

\author{
Jyh Wee Sew \\ Centre for Language Studies \\ Faculty of Arts \& Social Sciences \\ National University of Singapore \\ clssjw@nus.edu.sg
}

\begin{abstract}
This article examines existing studies of Malay verbs by major local Malay scholars. An interesting finding from the review is that there is a lack of emphasis on aspect as a semantic category in Malay verbs. The lack of overt tense marking in Malay verbs suggests that the verbs operate according to an internal temporal framework. Hence, it is necessary to highlight aspect as the underlying semantico-syntactic operator in Malay syntax guided with verb. To illuminate the point, verbal frames are incorporated as the necessary semantic template for the operation of Malay verbal prefixes in Malay phrases. The explication, based on existing linguistic notions of syntax and semantics, offers different interpretations of verb structures from previous studies to pave the way for a more detailed analysis of Malay verbs that factors in aspect as part of the phrasal construction.
\end{abstract}

Keywords: aspect, internal temporal structure, Malay grammar, Malay verbs, Malay verbal prefixes, temporal framework

\section{Prelude to Malay Aspect}

In the existing studies on Malay verbs few have mentioned anything substantial on Malay aspect. Despite the common grammar consensus that Malay verbs are devoid of tense, the process property inherent in the verbal category presupposes a temporal component as part of its semantic make-up. In fact, aspect is a common subcategory in languages throughout the world and is contended to be a more prototypical property than tense in the acquisition of first languages that have both tense and aspect (Lyons, 1977). As such, it can be established that Malay verbs, like verbs of other languages, manifest some kind of aspectuality may it be morphological codification, syntagmatic specification or contextual.

For a start, the categorisations of Malay verbs based on Abdullah Hassan (1982), Asmah Haji Omar (2009), Liaw (1985), and Nik Safiah Karim, Farid M. Onn, Hashim Hj. Musa (1996) are used as the foundation. The study of aspect in 
Indonesian by McCoy (1985) is used as a comparison to this analysis of Malay aspect. The difference between aspect and aktionsart becomes the consequential continuum to the analysis. The confusion between internal temporal content of Malay verbs and the manner in which a verb is unfolded, are sorted out. This is an important departure from previous work on aspect conflating both subcategories in the semantics of verbs (Comrie, 1993; Lyons, 1977).

Bache (1985) has made explicit that there is a need to tease out the distinction between aspect and aktionsart in order to attain a clear perspective of aspect in verbs. The aspectuality of verb according to Russian Academy of Grammar is adopted for Malay verbs. Bache's metacategory of aktionsart is imported into Malay verbal category. Nevertheless, I argue that the distinction between Malay aspect and aktionsart is feasible only as a theoretical construct. In reality the verbs is profiled as a process within an aggregation of manner and temporal alignment. Whichever way a verb is performed, the temporal component prevails as a pivotal domain of instantiation. To a certain extent one can choose to suspend the temporal domain may it be punctual or progressive but its existence remains inherent in the constituency of a verb.

The focus in this analysis is Malay reduplication with respect to aspect. It is evinced that verbal reduplication is an aspect marker in Malay. This type of morphology is used to signal progressivity in Malay. The particular morphology of Malay aspect manifest prototypically either by a basic verb stem to denote perfectivity, or a reduplicated verb to encode imperfectivity. Semantics wise, Langacker's (1990) insight on verbal aspect is adopted to explain the meaning of Malay verbal reduplication. The discussion ends with a macro verification of Malay verb reduplication as designating the imperfective aspect with data from the Malay newspapers.

\section{Malay Verbs}

According to Asmah Haji Omar (2009), Malay verb is defined as any word that functions as the predicate of a sentence. This definition applies to action verbs and situational verbs with action verbs are further classified into the following dichotomies:

Table 1

Verb dichotomies in Malay based on Nahu Melayu Mutakhir (2009)

\begin{tabular}{cc}
\hline Intentional & Non-intentional \\
\hline $\begin{array}{c}\text { membuka (open) } \\
\text { berdiri (stand) } \\
\text { memberi (give) }\end{array}$ & $\begin{array}{c}\text { jatuh (fall) } \\
\text { luruh (drop) } \\
\text { rebah (flop down) }\end{array}$ \\
\hline Reflexive & Non-reflexive \\
\hline mandi (bathe) & jual (sell) \\
tidur (sleep) \\
baring (lie down)
\end{tabular}




\begin{tabular}{|c|c|}
\hline Causative & Non-causative \\
\hline bunuh (kill) & mati (die) \\
\hline $\begin{array}{c}\text { basuh (wash-to cause } \mathrm{X} \text { to be } \\
\text { clean) }\end{array}$ & datang (come) \\
\hline merahkan (making $\mathrm{X}$ red) & kejar (chase) \\
\hline Creative & Non-creative \\
\hline masak (cook) & buka (open) \\
\hline jahit (sew) & makan (eat) \\
\hline buat (make) & cucuk (pierce) \\
\hline Mutual & Non-mutual \\
\hline berpeluk (to hug) & tegur (to scold) \\
\hline berbual (to chat) & menggaji (to study) \\
\hline bersalam (to shake hands) & memaki (to curse) \\
\hline Perfective & Imperfective \\
\hline berdering (ringing) & berdering-dering (continue ringing) \\
\hline berlari (running) & berlari-lari (continue running) \\
\hline memandang (looking) & memandang-mandang (continue looking) \\
\hline Habitual & Non-habitual \\
\hline bekerja (to work) & memukul (to hit) \\
\hline berjual (to sell as a profesion) & menjual (to sell as one event) \\
\hline berabdi (enslaven to) & tertawa (laugh) \\
\hline Moving & Non-moving \\
\hline pergi (go) & tidur (sleep) \\
\hline terbang (fly) & bernyanyi (sing) \\
\hline ambil (take) & berdiri (stand) \\
\hline
\end{tabular}

Situational verbs, on the other hand, are classified into four categories, namely, event, possessive, descriptive and cognitive verbs. Among some of the examples provided by Asmah Haji Omar (2009) are as follows:

Table 2

Situational verbs in Malay based on Nahu Melayu Mutakhir (2009)

\begin{tabular}{cccc}
\hline Event verbs & Possessive verbs & Descriptive verbs & Cognitive verbs \\
\hline sakit (sick) & ada (have) & menjadi (be) & fikir (think) \\
menang (win) & punya (possess) & merupakan (is) & ingat (recall) \\
sembuh (recover) & memiliki (own) & terdiri (comprise) & percaya (believe) \\
\hline
\end{tabular}


In Tatabahasa Dewan the prescriptive Malay grammar, Malay verbs are divided into a transitive and intransitive dichotomy. Transitive Malay verbs are split into active and passive voices. Intransitive Malay verbs are separated further into those with complements and without complements (Nik Safiah Karim et al. 1996):

Table 3

Classification of Malay verbs based on Tatabahasa Dewan (1996)

\begin{tabular}{cccc}
\hline \multicolumn{4}{c}{ Malay Verbs } \\
\hline Transitive Verbs & \multicolumn{2}{c}{ Intransitive Verbs } \\
\hline Active & Passive & + Complement & - Complement \\
\hline makan (eat) & dimakan (eaten) & tinggal (stay) & bangun (stand) \\
minum (drink) & diambil (taken) & ada (have) & menangis (cry) \\
mengambil (take) & diminum(drank) & menjadi (become) & menjerit (shout) \\
\hline
\end{tabular}

Liaw (1985) has listed many types of verbs in Malay. I choose to list the following as the major verbal types commonly found in Malay.

a) Transitives (makan (eat), tulis (write), ikat (tie)...)

b) Intransitives (turun (descend), senyum (smile), sembahyang (pray)...)

c) Ditransitives (memberikan (to give), membelikan (to buy)...)

d) Catenatives (duduk menangis (sit-cry), pergi melihat (go watch)...)

e) Copulatives Verbs (verbs that require complements: kelihatan (seem)...)

Three other categories of Malay verbs in Liaw (1985) are not included, namely, Transitive and Intransitive Verbs, Pseudo Transitive Verbs, and Complex Transitive Verbs. They are considered as variants of either the Transitive or Intransitive Verbs. Similar to Nik Safiah Karim et al. (1996), Abdullah Hassan (1982) divides Malay verbs into the typical transitive and intransitive bipartite with a further division of Malay intransitive verbs into dynamic (menangis (cry), terbang (fly), jatuh (fall)...); and static (tidur (sleep), mati (die)...).

In comparison, only Asmah $\mathrm{Hj}$. Omar's (2009) listing contains a fragment of semantic explication in terms of aspectuality as she provides a subdivision of perfective and imperfective bipartite in her categorisation of action verbs in Malay. However, her description is a structural taxonomy of Malay verbal category with semantics playing a secondary role. For if semantics is to be the ultimate criterion for verbal classification in Malay verbs, Asmah (2009) would have profiled perfectives and impertives as the major distinction to her 16 subtypes of Malay verbal classification. That the aspectuality of Malay verbs is classified as a subcomponent of the verbal categorisation reflects a limited attention on aspect. This discussion offers aspect as the major semantic element to Malay verbs as compared to Nik Safiah Karim et al. (1996), Liaw (1985) and Abdullah Hassan (1982) who seem to focus on transitivity in Malay verbs. One reason for the lack of attention to aspectuality could be that Malay verbs are utterly tenseless. Therefore the internal temporal content is less obvious, though no less significant as each verb 
denotes a process and each process pre-supposes an internal temporal dimension (Sew, 2007).

McCoy (1985) studied aspect in Indonesian in a more detailed analysis. From her survey of the literature she notices the similar linguistic phenomenon that there is no systematic study being carried out in Indonesian with respect to aspectual reference. The aspectual domains in Indonesian identified by McCoy are "inchoative, progressive, durative, perfective, frequentative and momental" (1985, p. 108). The codification of aspect in Indonesian verbs may thus have the following variants:

Table 4

Aspect of Malay verbs based on McCoy (1985)

\begin{tabular}{cc}
\hline Aspectual & Reference \\
\hline "Neutral" & $\begin{array}{r}\text { Pengemis itu makan di bawah pohon besar itu. } \\
\text { The beggar eats under that big tree. }\end{array}$ \\
"Inchoative" & $\begin{array}{r}\text { Pengemis itu pun makanlah di bawah pohon besar itu. } \\
\text { The beggar starts to eat under that big tree. }\end{array}$ \\
"Progressive" & $\begin{array}{r}\text { Pengemis itu sedang makan di bawah pohon besar itu. } \\
\text { The beggar is eating under that big tree. }\end{array}$ \\
"Durative" & $\begin{array}{c}\text { Pengemis itu makan-makan di bawah pohon besar itu. } \\
\text { The beggar has been eating under that big tree. }\end{array}$ \\
"Perfective" & $\begin{array}{c}\text { Pengemis itu sudah makan di bawah pohon besar itu. } \\
\text { The beggar has already eaten under that big tree. }\end{array}$ \\
"Frequentative" & $\begin{array}{c}\text { Pengemis itu selalu makan di bawah pohon besar itu. } \\
\text { The beggar always eats under that big tree. }\end{array}$ \\
& Pengemis itu tiba-tiba menelan biji buah itu. \\
"Momental" & Suddenly the beggar swallowed the seed of the fruit.
\end{tabular}

As the focus in this discussion is on verbal reduplication, the adverbial expressions that designate the aspectual reference are not the concern of this study. It is interesting to note that the verb /makan/ eat is an unconventional lexical item in Malay as it does not require prefixation in the written form. Indeed, /makan/ is a stand alone verb. It stands grammatically bare in form either in spoken or written. A different perspective can be profiled with the more conventional Malay verb, which requires prefixation in order to be deemed grammatical within the norm of Malay pedagogy. If we replace the verb /makan/ with /jalan/ (walk), for example, the progressive aspect shall require the prefix /ber-/ as either an inchoative, or habitual verbal marker. The same may be said for the frequentative aspect where the prefix /ber-/ is part of the verbal morphology in standard Malay. 
Also noticed in the momental aspect in McCoy's (1985) example is the fact that the prefix /me-/ is not explained as whether it has any contribution to aspectuality. Adhering to the langue of standard Malay, I can well exclude the adverbial /tiba-tiba/ and prefix the verb /telan/ swallow with the polysemous Malay /ter-/ to maintain the momental reading in a Malay expression i.e. pengemis itu telan biji buah. Although it is tempting to conclude that the verbal prefixation is related to aspectuality in Malay, it is worthwhile to extend a more refined distinction between aspect and aktionsart in Malay. The following discussion on the difference between the two shall offer a more restraint theoretical distinction towards a more accurate categorisation of Malay aspectuality and aktionsart.

\section{Aspect}

Aspect is concerned with the internal temporal content of a verb. Simply put, aspect of the verb is either a complete punctual process within a definite time span, or a progressive process that prolongs through time. Aspect encompasses the dynamics of a situation with respect to a progressive or a simple form. The former denotes an incomplete i.e. a developing situation and the latter refers to a situation as complete. Comrie (1993) has made it clear that tense is distinct from aspect. Tense is a deictic category that locates situations in time with reference to the present moment whereas aspect is concerned with the internal temporal make-up of a situation. In Comrie's words, tense is about situation-external time and aspect refers to situation-internal time.

Aspect can exist in the past tense either in the form of perfective, or imperfective as in these examples respectively, "He was laughing" and "He laughed". Comrie defines aspects as "different ways of viewing the internal temporal constituency of a situation" $(1993$, p. 3), which are generally found to be in either one of the prototypical oppositions, namely perfective and imperfective. Comrie further expounds that,

... the perfective looks at the situation from outside without necessarily distinguishing any of the internal structure of the situation, whereas the imperfective looks at the situation from inside, and as such is crucially concerned with the internal structure of the situation, since it can both look backwards towards the start of the situation, and look forwards to the end of the situation, and indeed is equally appropriate if the situation is one that lasts through all time, without any beginning and without any end. (p. 4)

Comrie's (1993) idea of aspectuality is the basic working framework for the explication of Malay aspect in the study of Malay verbal reduplication. It is rather fortunate that there is no tense inherent in the Malay verbs. In other words, Malay processes as codified in verbs need not be accounted with external temporal reference in relation to the zero-deictic-point. The complicated aspectuality such as "past perfective, present perfective, past imperfective, present imperfective and future imperfective" in the formal aspect of Russian (Bache 1985, p. 34), for example, does not surface in Malay. The aspectuality of Malay verbs can be assigned 
to the dichotomy of Perfective and Imperfective as the prototypical meanings. I adopt the meta-semantics suggested by The Russian Academy of Grammar as cited in Bache $(1985$, p. 59) into Malay:

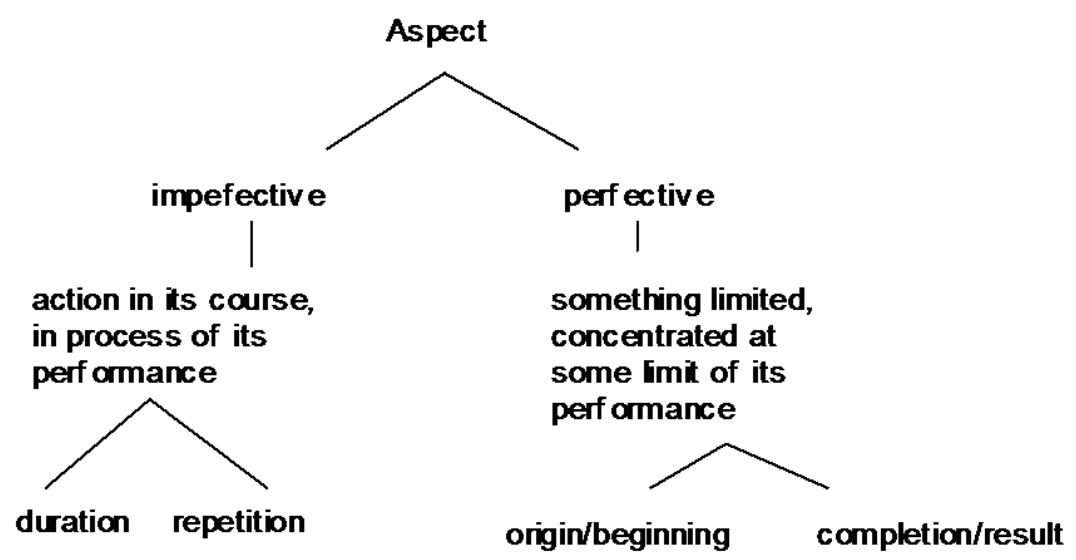

Figure 1. Russian meta-semantic divide

A debate on the inadequacy of Comrie's (1993) attempt to conflate aspect with aktionsart was pointed out by Bache. Bache (1985) sees the same problem in Lyons' work (1977) as well and argues that it is mandatory to distinguish the difference between aspect and aktionsart. I examine Comrie's standpoint with respect to Bache's allegation. In a footnote, Comrie points out the difference between aspect and aktionsart in linguistics:

... the distinction between aspect and aktionsart is drawn in at least the following two quite different ways. The first distinction is between aspect as grammaticalisation of the relevant semantic distinctions, while aktionsart represents lexicalisation of the distinctions, irrespective of how these distinctions are lexicalised; this use of aktionsart is similar to the notion of inherent meaning (related to the general semantic definition of aspect given above)...The second distinction, which is that used by most Slavists, and often by scholars in Slavonic countries writing on other languages, is between aspect as grammaticalisation of the semantic distinction, and aktionsart as lexicalisation of the distinction provided that the lexicalisation is by means of derivational morphology...In view of the confusion that can be caused by these two rather different senses of aktionsart, this term will not be used in the present book. (p. 7)

Contrary to Comrie (1993), Bache (1985) points out the difference between aspect and aktionsart. These two categories can be differentiated from a notional standpoint by ascribing separate sets of values to them respectively. Aktionsart can be defined in terms of "the type of situation expressed" whereas aspect can be understood in terms of "the speaker's view of the situation" (Bache, 1985, p. 94). I adopt the diagrammatic definition above as the general notion of Malay aspect. Aktionsart, on the other hand, is defined in the following section. 


\begin{abstract}
Aktionsart
According to Bache $(1985$, p. 11$)$, aspect can be regarded as types of verbal meanings that are concerned specifically with "the manner in which an action or a situation is performed or takes place". This is an interesting distinction, which detaches the mannerism of which a verb is carried out from the aspectuality i.e. the temporal constituency of the action. I adopt this division in the study of Malay verbal reduplication. On the one hand, Malay verbal aspect, similar to the Russian verbal counterpart, is defined generally into two categories, namely, perfective and imperfective. On the other, Malay aktionsart refers to the manner in which the verb is performed.

Both Malay aspect and aktionsart are regarded as a morphological category, although it is well understood that Malay aspect can be codified with syntactic specification such as the adverbial modification (McCoy, 1985). The second distinction with respect to aspect and aktionsart mentioned but disregarded in Comrie (1993) is now reiterated and subscribed as the operating notion for Malay verbal semantics: aspect is the grammaticalisation of the verbal semantic destinction and aktionsart is derivational lexicalisation of the distinction in question.

The core attribute in defining aktionsart, according to Bache $(1985$, p. 109) is " \pm actionality with respect to the phasal consituency of a situation". This phasal constituency results in four binary oppositions of aktionsarten in language. They include complexity versus simplicity, punctuality versus duration, telicness versus homogeneity, and direction versus self-containment. The full configuration of the aktionsart chain can be represented by Bache's Meta-category of Aktionsart

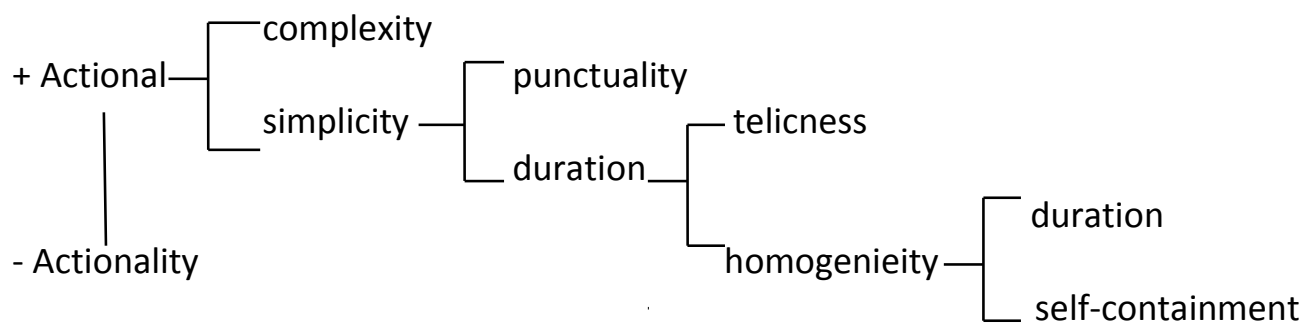

Figure 2. A meta-categorisation of Aktionsart

\title{
A Metacategory of Aktionsart and Aspect for Malay Verbs
}

At this point it is established that aktionsart and aspect are two separate semantic categories. The former concerns with the mannerism in which a verb is carried out, whereas the latter designates the profile of the verb either from internal or external viewpoints by the speakers. However, it is misleading to belief that the two categories are always exclusive of one another in the profiles of Malay verbs. The inter-categorical overlap of aspect and aktionsart is inevitable as the temporal profile of a verb underlies the manner in which the verb is performed by the agent or to the patient irrespective to the processual profile of the verb. 
The confluence of aktionsart-aspect is accountable when the development of verbal process is placed in the cognitive model of energy flow. The prototypical procedural configuration of a verb is equated with the flow of energy from the canonical agent through an instrument to a patient. The semantic notion of patient is termed as victim in traditional Malay grammar. No matter in what manner the energy is unleased and whether the process is profiled as a complete or partial trajectory of the energy flow, the verbal profile shall nevertheless be underlined by a temporal axis. Both the flow of energy in a particular manner and the existence of a temporal constituency within the energy flow constitute an overlap of aktionsart and aspect culminating to a fusion of aktionsart and aspect as one unitary category understood by some scholars such as Comrie (993) and Lyons (1977) is not a surprise.

Even Bache (1985) who champions three distinct subcategories of tense, aktionsart and aspect to the verbal category, formulates a combined diagram of aktionsart and aspect for his analysis of Russian verbs. This discussion incorporates Bache's twinning of aktionsart and aspect as a possible alternative to the description of Malay prefixed and/or reduplicated verbs but maintains a distinguished categorisation of aspectuality as the grammaticalised distinction in the semantics of Malay verbs. Bache's interplay of aktionsart and aspectuality is formulated as follows:

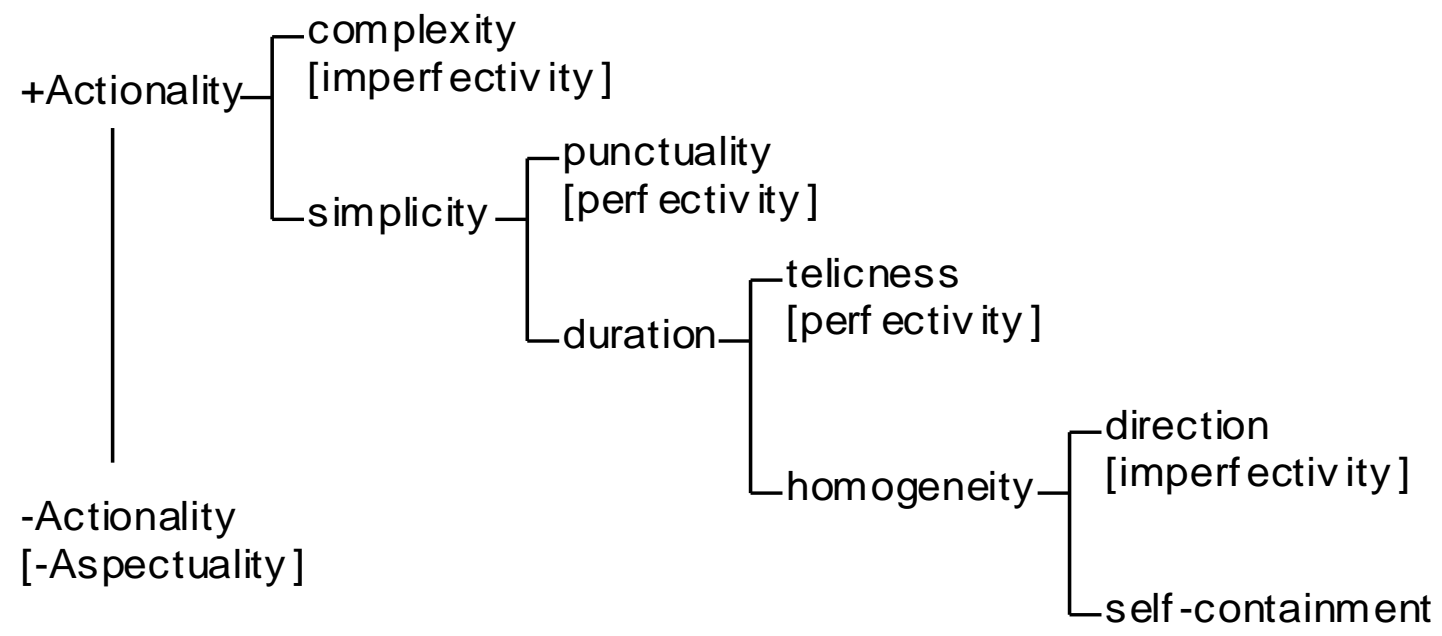

Figure 3. A semantic model combining aktionsart with aspect

With this enriched framework we can now classify the written forms of Malay verbs in general. The remainder of this article deals with verbal classification in terms of aktionsart and/or aspect with respect to prefixed verb and reduplicated verb forms respectively in written Malay. The prefixed forms of the Malay verbs are equated with the simple forms in English verbs and the Malay reduplicated verbs correspond to the progressive forms in English verbs. 


\section{Malay Aktionsart}

Asmah Haji Omar (2009, p. 135) explains that Malay verbs are characterised by these affixes namely; "/me(N)-/1 , /ber-/; /ter-/, /per-/; /di-/; /-kan/ and /-i/", among others. Asmah's explication clearly shows that she is referring to the written version of Malay as spoken Malay may be used without prefixation.

Malay verbs are mostly prefixed within a sentence. The salience of verbal prefixation can even be seen in reduplication, as bare verb stem reduplication is marginal compared to prefixed verb reduplication in Malay. This is contrary to nouns, which are reduplicated extensively in free forms. The significance of verbal prefixes necessitates a closer linguistic investigation. I examine the basic verb configurations in Malay morphology. Our focus is on the valence relations of four verbal prefixes in Malay namely /meN-/, /beR-/, /teR/, /di-/ in the composite structures of Malay verbs in written Malay. These prefixes are respectively known to be the active volitional, middle voice, stative and passive volitional markers for verbs in written Malay.

\section{Verbal Prefixation, Valence and Its Reconfiguration}

I supply two accounts of verbal prefixation from Sneddon (1996) and Benjamin (1993) repectively. The outlines of the meanings of the verbal prefixation in question are further employed in the establishing of grammatical valence of Malay composite structures within the asymmtery of stem-affix correspondence. Finally by using Cognitive Grammar's (CG) valence explanation I attempt to reconfigure the categorisation of Malay verbal prefixes in Wee (1995).

\section{verbal prefixation ala Sneddon.}

In Sneddon (1996) /meN-/, /beR-/ and /di-/ are considered to be primary prefixes in Malay. They provide primary prefixation to verbs to derive primary verbal structures. All primary transitive verbs are prefixed with /meN-/ in the active voice and /di-/ in the passive voice. All primary intransitive verbs are prefixed with /beR-/. A few intransitive verbs that are found to be marked by /meN-/ listed by Sneddon (1996, p. 65) include the following:

Table 5

Intransitive Malay verbs based on Sneddon (1996)

\begin{tabular}{|c|c|c|}
\hline menangis (cry) & mendidih (boil) & melapor (report) \\
meledak (explode) & menyanyi (sing) & mengeluh (complain) \\
meluncur (slide) & menikah (marry) & menyorok (hide) \\
melompat (jump) & menyerah (surrender) & menelentang (lie on the back \\
mengunsi (flee) & menginap (spend the night) & \\
\hline
\end{tabular}

At this point /meN-/ is determined as the prototypical dependent structure in Malay verb morphology that marks active transitive action: 
1. a. Abdullah membaca buku Abdullah meN-read book

b. Abdullah menangkap pencuri itu Abdullah meN-catch the thief

The fact that it is also found marking a few intransitive verbs as shown above can be explained as a semantic extension from the prototypical [meN-] schema as the transitive marker in Malay. This is justified by the distributions of transitive marking from /meN-/ which outnumber the intransitive marking.

/beR-/ is ascertained as the prototypical intransitive component in a verb prefixation in a Malay verbal composite structure:

2. a. Dia bermain di tepi sungai

$\mathrm{S} /$ he ber-play at side river

$\mathrm{S} /$ he is playing by the river.

b. Ali bergambar di sekolah

Ali ber-photo at school

Ali has his photo taken at school

/di-/ is established as the prototypical passive transitive component structure in the composite verbal structure in Malay:

3. a. Mereka dipukul oleh emak

They di-beat by mother

They were beaten by mother

b. Kari dimasak dengan santan

Curry di-cook with coconut milk

The curry was cooked with coconut milk

The prefix /teR-/ is regarded as the secondary prefix providing secondary verbal prefixation. According to Teeuw (1959), there was no evidence of /teR-/ in Old Malay only /mam/, /ni/ and /mar/ which are regarded to be cognate with $/ \mathrm{meN}-/$, /di-/, and /beR-/. Malay verbs can inherit three different semantic markings from /teR-/:

4. Stative

a. Sekolah saya terletak di tepi sungai

School I ter-locate at side river

My school is located at the river bank

5. Accidental

a. Dia terambil buku saya 
S/he ter-take book I

S/he has accidentally taken my book

6. Abilitative

a. Dia tidak termakan nasi itu

S/he NEG ter-eat rice ART

$\mathrm{S} / \mathrm{he}$ could not finish eating the rice

According to Sneddon (1996) all stative ter-verbs correspond to basic passive verbs which describe the state results, all accidental ter-verbs can be transitive passive or intransitive, and all abilitative ter- verbs are transitive passive.

\section{Malay verbal prefixation ala Benjamin.}

Benjamin (1993) has classified the first /meN-/ to be marking active voice, the second /ber-/ marking middle voice, the last /di/ for marking passive voice. Benjamin (1993, p. 356) explains that "the orientation markers are attached to the predication verb-stem; the subject orientation markers are prefixed and the object (i.e. predicate-complement-) markers are suffixed". This point is best demonstrated by his configuration of these prefixes in a Standard Malay syntactic schema (I have excluded /per-/ from Benjamin's schema):

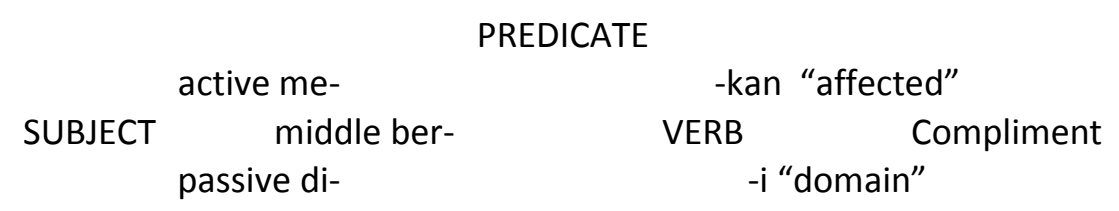

I leave out Benjamin's anthropological perspective on transitivity and focus on his view on /ber-/. Benjamin finds notions like "intransitive" and "object-incorporating" unsatisfactory to describe the function of $/$ ber- $/$. He prefers the notion of "centripetal", or the notion of "internal". /ber-/ is said to have the valency reducing properties, which could be attributed to grammatical subject, which is psychosocially divided. Benjamin illustrates that the notion of psychosocial division as follows (1993, p. 375):

"saya bercukur" (I shave myself)

The subject is simultaneously the agent and patient hence the source and goal of its own action. The same reflexive function is attributed to sentences like:

$$
\begin{array}{|l|}
\hline \text { saya bertopi (I wear a hat) } \\
\hline \text { saya berkeretapi (I ride in a train) } \\
\hline
\end{array}
$$


In habitual predication like:

Dia bertenun (S/he is weaving)

The subject is said to be divided temporally. In inalienability like /berbapa/ (to have as father) /ber-/ is further equated to be the Malay middle voice occupying the ground between active and passive.

Benjamin (1993) also points out that /teR-/ cancels the sense of in progress and designates the perfected-state meaning. He doubts the various functions of /teR-/ which include unintentional active, unintentional passive, perfective, abilitative, unintentional volitive as outlined by Abdullah Hassan (1982). The nonintentional meaning of this prefix is said to reflect the Malay ethos of subsuming to the almighty, which is consonant with Winstedt's (1957) point that the non-agentive meaning is the basic meaning.

\section{Malay Cognitive Verbal Frames}

In the probing of Malay verbal composite structures within the framework of cognitive grammar, the syntagmatic relationship between a prefix and the verb base is translated into the valence relation between a dependent structure (prefix) and a content unit (verb). The prefixes or dependent structures form a symbolic asymmetrical valence to the content verbs or autonomous structures in the sense that the conceptually dependent structure pre-supposes the autonomous structure as part of its internal structure (Langacker 1990, p. 122). The internal properties of a dependent structure are integrated to the autonomous structure as an elaboration site (e-site).

The asymmetry can be taken to be a "spike-hole" metaphor. The dependent structures /meN-/, /di-/, /ber-/, /ter-/ provide the "holes" to be filled by the "spikes" of content verbs (Tuggy, 1992). The function of each prefix is to determine the profile of the content verb it depends on. The verbal composite structures are related with Croft's (1990) prototypical event views namely causative, inchoative and stative. The event structures are symbolised schematically in these verbal prefixes.

I identify valence of each Malay prefix. The Malay verb, sell /jual/ is a conceptually autonomous structure which is also regarded as an un-analisable unit in cognitive grammar. It can integrate symbolically with the dependent structure of Malay a prefix /meN-/ to form a composite structure:

$[[\mathrm{MEN}]-[\mathrm{JUAL}]] /[[$ menjual $]]$

The prefix is a dependent structure, which becomes the profile determinant of the composite structure as it provides the e-site to be elaborated by the internal structure of the content verb. The same symbolic integration applies with prefixes /ber-/, /ter-/ and /di-/: 


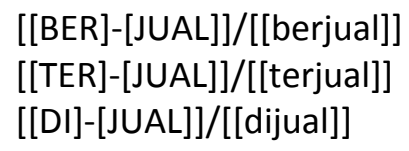

All the prefixes are dependent on the content verb/jual/ as they are presupposed to be part of the content verb as their internal structures. Some structures of each prefix correspond to the autonomous verb structure as a whole and exist in a schematic relation to the content verb. The content verb /jual/ elaborates the content of each e-site (prefix) respectively specifying in greater detail the meaning of each prefix which remains schematic in its unintegrated (free) form (schema in cognitive grammar is equated with rules). The elaboration of the e-site of a dependent structure by the autonomous structure constitutes a grammatical valence in cognitive grammar.

This leaves us to ascertain the semantic schemas of the verbal prefixes, /meN-/, /ber-/, /ter-/, /di-/. I adopt Croft's (1990) classification of event types to categories Malay verbs and to account for the various functions of verbal prefixation in Malay. Cross-linguistically, verbs can be classified into three event types namely the causative, inchoactive and stative (Croft 1990). Another important point made by Croft is the capability of languages in the world to coerce a verb root into one of the three event types by means of ancillary morpho-syntax which he calls conversion.

The grammatical process of the morphology conversion includes causativising, detransitivising, passiving and stativising. All these conversions can be seen as correspondences within grammatical valence relations between the Malay dependent structures /meN-/, /beR-/, /teR-/, /di-/ and the autonomous structures of various content verbs. In other words, verb prefixation in Malay morphology has valence significance in the identification of various event types. This conceptulisation of event structures become the categorising basis of various Malay verb meanings within a clause.

Different prefix profiles a particular manner of action path or energy flow with respect to trajector and landmark alignment. The prefix foreshadows the construal of an event. The multifarious but regular patterns of Malay verbal construals portended by the prefixes in a series of valencies manifest the ability of human cognition to perceive, structure and construe the motion verbs in Malay and other languages in alternate prototypical configuration. Malay verbal prefixes profile these basic meanings:

/meN-/ is the prefix prototype for causative events: transitivising /ber-/ is the prefix prototype for inchoactive events: inchoating /ter-/ is the prefix prototype for stative events: stativising /di-/ is the prefix prototype for passived causative events: passiving

The above patterns are by no means absolute. In cognitive grammar as any grammatical unit is capable of undergoing semantic extension within a network of schemas. Schemas, according to Langacker $(1990$, p. 113) are "abstract in relation to content units or actual expression...a schema can differ from instantiating content 
structures only in degree of specifity, and can never be substantially different in kind". Furthermore,

... schema are more closely analogous to rules and grammatical classes than to deep structures; they bear a relation to their instantiations that can be considered PARADIGMATIC. A schema captures a generalization and categorizes a series of content structures which are parallel in formation; it does not relate one content structure to another, except in the sense of expressing their similarities. (Langacker: 1990, p. 114)

A schema in cognitive grammar embodies the generalisation, which is extractable from an array of content units and the grammar of a language is conceived in cognitive grammar as a structured inventory of conventional linguistic units, which involves the co-existence of schematic and content units. The latter elaborate the former in an interactive relation (Langacker 1990, pp. 103-104). The Malay verbal prefixes are schemas in terms of cognitive grammar. Each prefix is a dependent schematic unit, which provides an elaboration site to a content verb. The semantic extensibility of a schema integrates the additional senses of a prefix as semantic variants into the semantic network.

From the four patterns of Malay prefixes, /di-/ can be safely ascertained as the schema of causative event which profiles the patient in the construal of the event. All verbal component structures which take /di-/ as its e-site are passive constructions profiling the patient of a clause as its trajector. This is equivalent to the second variant [Perf 2 ] of English passive in Langacker's (1990, pp. 130-131) analysis.

Table 6

Passive constructions in Malay

\begin{tabular}{|c|l|}
\hline a. Ali dipukul oleh emak & b. Air kelapa dijual setiap petang \\
\hline Ali di-hit by mother & water coconut di-sell every evening \\
\hline Patient di-V Actor & Coconut water is sold every evening \\
\hline & Patient (Object) di-V Complement \\
\hline
\end{tabular}

$/ \mathrm{meN}-/^{2}$ is a causative schema in verbal prefixation with a semantic extension as intransitive marker for certain idiomatic verbal component structures as listed in Table 5 following Sneddon (1996).

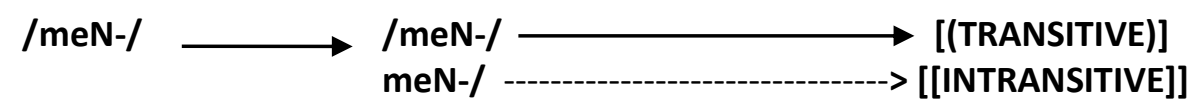

The first schematic meaning is represented in a full arrow to illustrate its prototype status as a meaning elaboration. The prototype meaning is given the parenthesis as the semantic takes on indefinite morpho-syntax conversion, which naturally is a novel schematicity. The second schematic meaning is represented by a broken arrow as intransitivity is not the prototypical function of /meN-/ in Malay. The non- 
prototypical meaning is represented in square brackets because each verbal component structure is a unit, which is learned and mastered by the Malay speakers as a convention in Malay.

It is plausible for /meN-/ with non-prototypical meaning as an intransitive schema. Taylor (1995) has pointed out the complexity of prototype effect which could lend support to explain the duality of grammatical role of $/ \mathrm{meN}-/$ hence the non-prototypical role for /meN-/ as profile determinant of intransitive verbs. They are explained as the conventional units in cognitive grammar. These intransitive meN-verbs are manipulated as "pre-packaged verbal composite structures" Malay speakers without attending specifically to its internal parts (Langacker 1990, p. 103).

Prototypical verbal prefixation of /meN-/ [(TRANSITIVE)]

Emak memukul Ali

mother meN-hit Ali

Actor meN-V patient

Ali menjual air kelapa setiap petang

Ali meN-sell water coconut every evening

Actor meN-V Patient Complement

Non-prototypical verbal prefixation of /meN-/ [[INTRANSITIVE]]

Air sudah mendidih

water already boiled

Pat aspect meN-boil

Ali menangis di universiti

Ali cried at university

Actor meN-cry PREP. LOC

/beR-/ is a middle voice marker in Malay (Benjamin, 1993). The schematic meaning of this prefix is inchoactive. Many researchers found difficulty in assigning the exact meaning to it other than pointing to the fact that the prefix makes a well-formed verb composite (cf. Sneddon 1996). However, others (for example, Benjamin, 1993) have also identified the reflexive meaning of this prefix as in these examples:

Dia bercukur sendiri (He shaves himself)

Saya menjahit sendiri (I sew for myself)

Aku bernyanyi sendiri menghibur hati (I sing myself to please my (own) heart)

Following Benjamin (1993), I include habitual into the inchoative meaning of the prefix. The possesive meaning is not our concern as the focus is on verbal prefixation rather than nominal (Sew, 2011). Reflexive is taken as the prototypical meaning whereas habitual is the extension. The act of brushing one's teeth, for example, illustrates that one is always brushing for oneself and it becomes a 
habitual process through repetition. Habitual is secondarily cultivated whereas reflexive is the inherent meaning of the action marked with /beR- $/$. The schema of the prefix /beR-/ is:

\section{/beR-/ $\longrightarrow[$ [INCHOATIVE-REFLEXIVE] ----------->[INCHOATIVE-HABITUAL]}

/teR-/ is the most polysemous of the four verbal Malay prefixes. Wouk (1980, pp. 86-87) singles nonintentionality out as the prototypical meaning for /teR-/ and claims that "the agent of a ter-verb is not responsible for the experience in the causal-event". In cognitive grammar's terms, the trajector of a clause elaborated by the composite verbal structure which has /teR-/ as its profile determinant is not responsible for the experience of the landmark. If we follow the prototype events outlined by Croft (1990) the problem with the polysemous /teR-/ is resolved as it is relegated to be a prototypical stative marker in verbal prefixation.

This prefix profiles the final state of the process which in turn equates it with imperfective. In its prototypical meaning as a schematic stative dependent structure, it profiles a complex atemporal relation rather than a process. This semantic is equivalent to the first variant of English passive [PERF 1 ] (Langacker, 1990).

The imperfective state could then be construed into various perfective interpretations as accidental and abilitative. The construal of the former is by foregrounding the landmark whereas the construal of the latter is by foregrounding the trajector which is also the actor (Sew, 1999).

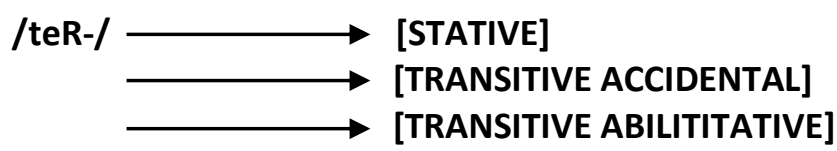

Pintu itu terbuka [Stative]

Door that ter-open

That door is opened

Dia terjatuh semalam [ACCIDENTAL]

$\mathrm{S} /$ he ter-fall last night

She fell down last night

Ali tidak terangkat batu itu. [ABILITATIVE]

Ali NEG ter-lift stone that

Ali could not lift that stone

\section{Wee's Reconfiguration of Verbal Prefixation in Malay}

Wee (1995) re-examines the paradigmatic set of voice markers in /meN-/, /beR-/, /di-/, /teR-/ and come to the conclusion that /meN/ is volitionally unspecified whereas /beR-/ is volitional and /teR-/ is non-volitional. The reconfigured Verbal Paradigm in Malay is: 
Table 7

Malay verbal paradigm based on the analysis in Wee (1995)

\begin{tabular}{ccc}
\hline Vol [ ] & Vol [+] & Vol [-] \\
\hline meN-: active & beR-: active & ter-: active \\
di-: passive & beR-: passive & ter-: passive \\
\hline
\end{tabular}

Wee's (1995) argument is not without problem. The fact that /beR-/ is a middle voice marker is ignored and it is given both active and passive voice specifications. He ignores the fact that $/ \mathrm{meN}-/$ is traditionally understood as marking volitional. His argument that /meN-/ does not specify volitionality is based on the fact that a meN-verb in Malay sentences can co-occur with either an adverbial of intentionality or unintentionality, as shown in his examples:

Ali meN-pukul John dengan sengaja

Ali meN-hit John with intention

Ali meN-pukul John dengan tidak sengaja

Ali meN-hit John with NEG intention

The second sentence suggests a conflict between the verb valence and the unintentional adverbial. This is due to the fact that /meN-/ is a volitional marker, a point which is already made clear by Benjamin (1993). In re-examining their work, Wee (1995) first poses the question as to why we cannot have the composite structure of *meN-ter Verb. This is simply due to the fact that the two prefixes conflict with each other in terms of volitionality where meN- is volitional and ter- is non-volitional hence this question is a nonissue.

\section{Conclusion}

In conclusion, the problem of active, or passive marking in Malay prefix is explicable with the figure and ground asymmetry in cognitive grammar. A passive clause is a patient profiled clause and an active clause is an agent profiled clause. The problem of volitionality is solved by adopting Croft's (1990) event views. Causative and inchoative is volitional whereas stative event is non-volitional. The fact that /meN-/ is a causative scheme renders it to be volitional. The same could be said for /beR- $/$, the inchoative schema. /teR-/ is a stative schema and consequently non-volitional. The non-volitionalilty of /teR-/ is considered to concur with the meaning of nonintentionality. The cognitive configurations of Malay Verbal Prefix are as follows:

Table 8

A semantic schema of Malay verbal prefixes

\begin{tabular}{ccc}
\hline Causative Schema & Inchoative Schema & Stative Schema \\
\hline meN- & beR- & teR- \\
di- & & \\
\hline
\end{tabular}


The trajector profiled by /meN-/ is always an agent within a prototypical causative event in Malay whereas the trajector in the profiled by /di-/ is always the patient within a prototypical causative event in Malay.

Notes

${ }^{1}$ I do not discuss the ditransitive of /meN-/ as it involves the suffix /-kan/. The reader is referred to (Bambang Kaswanti Purwo 1995) for a discussion based on functional grammar. Ong (2009) offers a recent study on ditransitive and transitive Malay verbs based on learners' grammar.

${ }^{2}$ For ease of symbolic representation and cognitive salient, I choose $/ \mathrm{meN}-/$ as the prototypical unit compared to /meNG-/ and /me( $\sim)$-/ which are both less activated symbolically in written form hence the latter two may be symbolically more novel. Although /meN-/ is the more conventionalised symbolic unit, Mintz (1994) has chosen /meng-/ as the prefix prototype. Similarly, based on Malay data, Yeoh (1988) offers a distributive explication in making a case for /meng-/ as a more basic morphemic segment compared to /meN-/.

\section{References}

Abdullah Hassan. (1982). Linguistik am untuk guru Bahasa Malaysia. Petaling Jaya, Malaysia: Penerbit Fajar Bakti.

Asmah Haji Omar. (2009). Nahu Melayu mutakhir. Kuala Lumpur, Malaysia: Dewan Bahasa dan Pustaka.

Bache, C. (1985). Verbal aspect: A general theory and its application to present-day English. Odense, Denmark: Odense University Press.

Bambang Kaswanti Purwo. (1995). The two prototypes of ditransitive verbs: The Indonesian evidence. In W. Abraham, T. Givón, \& S. A. Thompson (Eds.), Discourse, grammar and typology (pp.77-95). Amsterdam, The Netherlands: Benjamins.

Benjamin, G. (1993). Grammar and polity: The cultural and political background to Standard Malay. In W. A. Foley (Ed.), The role of theory in language description (pp. 341-92). Berlin, Germany: de Gruyter.

Comrie, B. (1993). Aspect. Cambridge, UK: Cambridge University Press.

Croft, W. (1990). Possible verbs and the structure of events. In S. L. Tsohatzidis (Ed.), Meanings and prototypes: Studies in linguistic categorization (pp. 48-73). London, UK: Routledge.

Langacker, R.W. (1990). Concept, image, and symbol: The cognitive basis of grammar. Berlin, Germany: de Gruyter.

Liaw, Y. F. (1985). Nahu Melayu moden. Singapura, Singaore: Pustaka Nasional.

Lyons, J. (1977). Semantics: Volume 2. London, UK: Cambridge University Press.

McCoy, I. H. (1985). Tense and aspect: A comparative study of meaning in English and Bahasa Indonesia. (Unpublished doctoral dissertation), University of Texas, Austin.

Mintz, M. W. (1994). A student's grammar of Malay Indonesian. Bukit Merah, Singapore: EPB Publishers. 
Nik Safiah Karim, Farid M. Onn, Hashim Hj. Musa, \& Abdul Hamid Mahmood. (1996). Tatabahasa Dewan. Kuala Lumpur, Malaysia: Dewan Bahasa \& Pustaka.

Ong, C.G. (2009). Kuasai struktur ayat Bahasa Melayu. Kuala Lumpur, Malaysia: Dewan Bahasa \& Pustaka.

Sew, J.W. (2007). Reduplicating nouns and verbs in Malay: A conceptual analysis. Lembah Pantai, Malaysia: University of Malaya Press.

Sew, J.W. (2011). Pandangan alternatif pada analisis semantik kognitif imbuhan BeR. GEMA Online Journal of Language Studies, 11(2), 155-170.

Sew, J.W. (1999). Kata kerja: Mempelopori suatu penilaian semantik baru. Jurnal Dewan Bahasa 43(6), 530-537.

Sneddon, J. N. (1996). Indonesian: A comprehensive grammar. London, UK: Routledge.

Teeuw, A. (1959). The history of the Malay language: A preliminary survey. Bijdragen Tot de Taal-, Land- En Volkenkunde, 115, 138-156.

Taylor, J. R. (1995). Linguistic categorization: Prototypes in linguistic theory. Oxford, UK: Clarendon Press.

Tuggy, D. (1992). The affix-stem distinction: A cognitive grammar analysis of data from Orizaba Nahuatl. Cognitive Linguistics, 3, 237-300.

Wee, L.H.A. (1995). Cognition in grammar: The problem of verbal prefixation in Malay. (Unpublished doctoral dissertation), University of California, Berkeley.

Winstedt, R.O. (1957). Malay grammar. London, UK: Oxford University Press.

Wouk, F. (1980). The TER- prefix in Indonesian: A semantic analysis. In P.B. Naylor (Ed.), Austronesian studies: Papers from the Second Eastern Conference on Austronesian Languages, (pp. 81-87). Michigan: University of Michigan.

Yeoh, C. K. (1988). Kajian semula tentang morfem dasar penanda aktif dalam Bahasa Melayu. In Farid M. Onn (Ed.) Bunga rampai fonologi Bahasa Melayu (pp. 132143). Petaling Jaya, Malaysia: Penerbit Fajar Bakti. 